\title{
Study of the glucoamylase promoter in Aspergillus niger using green fluorescent protein
}

\author{
Anne L. Santerre Henriksen, ${ }^{1}$ Sergine Even, ${ }^{1} \dagger$ Christian Müller, ${ }^{1}$ \\ Peter J. Punt, ${ }^{2}$ Cees A. M. J. J. van den Hondel ${ }^{2}$ and Jens Nielsen ${ }^{1}$ \\ Author for correspondence: Anne L. Santerre Henriksen. Tel: +45 4525 2698. Fax: +45 45884148. \\ e-mail: ash@ibt.dtu.dk
}

\footnotetext{
1 Center for Process Biotechnology, Building 223, Technical University of Denmark, DK-2800 Lyngby, Denmark

2 TNO Nutrition and Food Research Institute, Department of Molecular Genetics and Gene Technology, PO Box 360, NL-3700 AJ Zeist, The Netherlands
}

\begin{abstract}
An Aspergillus niger strain expressing a red-shifted green fluorescent protein (GFP) in the cytoplasm under the control of the glucoamylase promoter (PglaA) was characterized with respect to its physiology and morphology. Although xylose acted as a repressor carbon source during batch cultivations, PglaAdriven GFP expression by the glucoamylase promoter could be demonstrated in xylose-limited continuous cultures. In these cultivations, the xylose concentration was therefore too low to cause repression. Transient experiments initiated with a maltose pulse did not further induce red-shifted GFP production in xylose-limited continuous cultures. Maltose induction under conditions of xylose repression was microscopically observed and quantified in a flow-through chamber. Red-shifted GFP was first produced after $5 \mathrm{~h}$ induction. Finally the strain was characterized in glucose-limited continuous cultures, and here the area of the mycelium stained with cytoplasmic GFP increased with increasing specific growth rate, indicating that GFP can be used as a marker of cellular activity in this type of cultivation.
\end{abstract}

Keywords : glucoamylase promoter, Aspergillus niger, green fluorescent protein, chemostat

\section{INTRODUCTION}

Green fluorescent protein (GFP) from the jellyfish Aequorea victoria can be used as a reporter molecule to monitor gene expression and protein localization in vivo (Chalfie et al., 1994; Chalfie, 1995). GFP is a $27 \mathrm{kDa}$ monomer which requires oxygen for the chromophore formation but no additional cofactor, substrate or gene product from A. victoria. Native GFP emits green light at a peak wavelength of $509 \mathrm{~nm}$, with a shoulder at $540 \mathrm{~nm}$, when energy is transferred from the $\mathrm{Ca}^{2+}$ activated photoprotein aequorin to GFP. In eukaryotic or prokaryotic cells exposed to UV or blue light, GFP emits a bright green fluorescence. Fluorophore formation occurs by autocatalytic cyclization of three amino acid residues, $\mathrm{Ser}_{65}-\mathrm{Tyr}_{66}-\mathrm{Gly}_{67}$, in two steps: first cyclization and then oxidation by molecular oxygen (Cody et al., 1993; Prasher et al., 1992). Nascent unfolded GFP is not fluorescent, and the post-trans-

\footnotetext{
†Present address: Department of Biotechnology, Institut National des Sciences Appliquées, F-31077 Toulouse cedex, France.
}

Abbreviations: GFP, green fluorescent protein; HGU, Hyphal Growth Unit; PglaA, A. niger glucoamylase promoter. lational chromophore formation may therefore be a limiting step (Cody et al., 1993). GFP has been successfully expressed in a number of micro-organisms and plants (Webb et al., 1995; Cormack et al., 1997; Misteli \& Spector, 1997; Takada et al., 1997; Wang \& Hazelrigg, 1994; Plautz et al., 1996; Inouye \& Tsuji, 1994; Terry et al., 1995), and in filamentous fungi, it has been fused to a nuclear protein, StuA, to follow the nuclear migration during tip extension and growth of Aspergillus nidulans (Suelmann et al., 1997; FernandezAbalos et al., 1998). In this study we focused on the construction and characterization of an Aspergillus niger strain expressing GFP in the cytoplasm. The characterization was carried out using both batch and continuous cultures where the environmental conditions could be well controlled. This allowed studies of GFP production both at a steady state and under dynamic conditions. Moreover, image analysis techniques were used to describe the morphology of the strain.

\section{METHODS}

Recombinant strains. A GFP-expressing recombinant $A$. niger strain was obtained by introduction of a synthetic gene encoding red-shifted GFP (Sheen et al., 1995), under control of 
the $A$. niger glaA promoter (glaA is the glucoamylase gene) and $A$. nidulans $\operatorname{trp} C$ terminator $(\operatorname{trp} C$ is the anthranilate synthetase gene), to $A$. niger AB6.4 $\Delta$ pepE (Siedenberg et al., 1998) (pepE is the aspartic protease gene), which is a fawncoloured glucoamylase- and vacuolar-protease-deficient derivative of $\mathrm{AB} 4.1$.

Culture conditions. Batch cultivations were carried out in 51 bioreactors with 4.51 working volume equipped with four baffles and two Rushton four-blade disk turbines as described by Carlsen et al. (1996). The medium composition was the following: $0.75 \mathrm{~g} \mathrm{KH}_{2} \mathrm{PO}_{4} \mathrm{l}^{-1}, 1 \mathrm{~g} \mathrm{MgSO}_{4} .7 \mathrm{H}_{2} \mathrm{O} \mathrm{l}^{-1}, 1 \mathrm{~g} \mathrm{NaCl}$ $\mathrm{I}^{-1}, 0.1 \mathrm{~g} \mathrm{CaCl}_{2} \mathrm{I}^{-1}, 0.5 \mathrm{ml}$ trace element solution $\mathrm{I}^{-1}$ and $0.25 \mathrm{ml}$ antifoam SBS21 $\mathrm{l}^{-1}$. The trace element solution contained the following elements: $14 \cdot 3 \mathrm{~g} \mathrm{ZnSO}_{4} \cdot 7 \mathrm{H}_{2} \mathrm{O} \mathrm{I}^{-1}$, $2.5 \mathrm{~g} \mathrm{CuSO}_{4} .5 \mathrm{H}_{2} \mathrm{O} \mathrm{I}^{-1}, 0.5 \mathrm{~g} \quad \mathrm{NiCl}_{2} .6 \mathrm{H}_{2} \mathrm{O} \mathrm{l}^{-1}, 13.8 \mathrm{~g}$ $\mathrm{FeSO}_{4} \cdot 7 \mathrm{H}_{2} \mathrm{O} \mathrm{l}^{-1}, 6 \mathrm{~g} \mathrm{MnSO}_{4} \cdot \mathrm{H}_{2} \mathrm{O} \mathrm{l}^{-1}$. The batch cultures contained $7.3 \mathrm{~g}$ ammonium sulphate $\mathrm{l}^{-1}, 20 \mathrm{~g}$ glucose $\mathrm{l}^{-1}$ or $20 \mathrm{~g}$ xylose $\mathrm{l}^{-1}$ and $2 \cdot 44 \mathrm{~g}$ uridine $\mathrm{l}^{-1}$. The temperature was controlled at $30^{\circ} \mathrm{C}$ and the $\mathrm{pH}$ was kept constant at 3.5 by adding $2 \mathrm{M} \mathrm{H}_{2} \mathrm{SO}_{4}$ or $4 \mathrm{M} \mathrm{NaOH}$.

The continuous cultures were carried out in a 21 Braun bioreactor operated at constant mass. The bioreactor was fed with sterile medium with a fixed, constant flow rate $(F)$. The bioreactor was equipped with three load cells that were used to control the flow from the bioreactor by another pump. In this way, the bioreactor volume (or mass) could be kept constant $(V)$. By varying the flow rate of the sterile medium to the bioreactor the dilution rate $(D=F / V)$, which at steady state is equal to the specific growth rate, could be adjusted. The culture variables were assessed and controlled using the Shiva software developed by BIA, Ljubljana, Slovenia. The temperature was controlled at $30^{\circ} \mathrm{C}$ and the $\mathrm{pH}$ was kept constant at 3.5 by adding $2 \mathrm{M} \mathrm{H}_{2} \mathrm{SO}_{4}$ or $4 \mathrm{M} \mathrm{NaOH}$. Carbon dioxide and oxygen in the exhaust gas were measured on-line using an acoustic gas analyser as described previously (Christensen et al., 1995). The feeding medium was the same as the one used for the batch experiments except for the ammonium sulphate and the uridine, which were reduced to $2.5 \mathrm{~g} \mathrm{l}^{-1}$ and $0.488 \mathrm{~g} \mathrm{l}^{-1}$, respectively. The continuous cultures were carbon-limited, with either glucose $\left(4 \mathrm{~g} \mathrm{l}^{-1}\right)$ or xylose $\left(3.5 \mathrm{~g} \mathrm{l}^{-1}\right)$ as the carbon source. The concentrations of the different carbon sources were chosen such that the concentration on a C-mol basis was the same.

Batch cultivations were inoculated with freely dispersed hyphal elements to a biomass concentration of $0 \cdot 2-0 \cdot 3 \mathrm{~g}$ dry weight $(\mathrm{kg} \text { medium })^{-1}$. The freely dispersed mycelium was obtained from shake flasks containing the same medium inoculated with spores. The continuous cultures were also inoculated with freely dispersed hyphal elements from a batch culture carried out at $\mathrm{pH} 3 \cdot 5$.

The biomass concentration was measured by the gravimetric method. Samples for analysis of the intracellular protein level were removed as rapidly as possible and immediately filtered and frozen in liquid nitrogen. All samples for intracellular analysis were kept frozen at $-80^{\circ} \mathrm{C}$ until analysed.

Extracellular measurements. Glucose was measured on a COBAS MIRA automatic pipetting machine/spectrophotometer (Roche Diagnostics). The samples were diluted in order to be in the linear range from 1 to $10 \mathrm{mg} \mathrm{l}^{-1}$. The glucose detection assay is based on phosphorylation of D-glucose by hexokinase to form glucose 6-phosphate. Glucose 6-phosphate is converted to gluconate 6-phosphate with concurrent conversion of $\mathrm{NAD}^{+}$to NADH catalysed by glucose-6-phosphate dehydrogenase. The NADH formation, which can be measured spectrophotometrically at $340 \mathrm{~nm}$, is related to the glucose concentration in the sample (Banauch et al., 1975). The maltose concentration during the pulse experiment was determined in the same way as glucose after treatment of the diluted samples in the range of $5-0.5 \mathrm{mg} \mathrm{l}^{-1}$ with 2 units $\alpha$-glucosidase as defined by Boehringer Mannheim for $2 \mathrm{~h}$ at $37^{\circ} \mathrm{C}$.

Xylose and organic acids were detected and quantified by standard HPLC equipped with an anion-exchange column, Aminex HPX-87H, and a refractometer for xylose, oxalic acid and malate and a UV detector for pyruvate, operated at $65^{\circ} \mathrm{C}$ with $5 \mathrm{mM} \mathrm{H}_{2} \mathrm{SO}_{4}$ as eluent at a flow rate of $0.6 \mathrm{ml} \mathrm{min}^{-1}$.

Intracellular measurement of GFP. The mycelium (between 10 and $20 \mathrm{mg}$ wet wt) was disrupted using a Retsch bead-mill for $15 \mathrm{~min}$ with $0.5 \mathrm{ml}$ glass beads $(0.75-1.0 \mathrm{~mm})$ and $0.5 \mathrm{ml}$ Tris/tricarballylate buffer, pH $7.8 \quad(0.4 \mathrm{M}$ Tris, $0.15 \mathrm{mM}$ tricarballylic acid, $50 \mathrm{mM} \mathrm{MgCl}, 25 \%$ glycerol), at $4{ }^{\circ} \mathrm{C}$ (Cocaign-Bousquet et al., 1996). The samples were centrifuged ( $10 \mathrm{~min}, 13500 \mathrm{~g}, 4^{\circ} \mathrm{C}$ ) and the supernatant containing the intracellular proteins was collected and stored at $-20^{\circ} \mathrm{C}$.

Total protein concentration was measured on a COBAS MIRA automatic pipetting machine/spectrophotometer. The samples were diluted to produce protein concentration readings within the linear range of the Bradford (1976) assay (Bio-Rad) (from 50 to $500 \mathrm{mg} \mathrm{BSA} \mathrm{l}^{-1}$ ).

Two methods were simultaneously used to analyse the GFP concentration in the cells. SDS-PAGE, $15 \%$ Excel gel (Pharmacia Biotech), was used to follow the production of intracellular protein. The intracellular extracts were applied on an SDS-PAGE gel according to the method described by the manufacturer (Pharmacia Biotech). After silver staining, the amount of GFP was quantified by comparison with a standard curve of red-shifted GFP using the CREAM software (Kem-EnTec). A fluorescence spectrometer LS 50-B (Perkin Elmer) was used to quantify the chromophore by comparison with a standard curve of red-shifted GFP $\left(0.01-0.5 \mathrm{mg} \mathrm{l}^{-1}\right)$ (Clontech). The excitation and emission wavelengths were $470 \mathrm{~nm}$ and $510 \mathrm{~nm}$, respectively.

Fluorescence microscopy. A sample, taken from the bioreactor, was diluted in order to disperse the hyphal elements. The diluted sample was stained with calcofluor white $\left(0.023 \mu \mathrm{g} \mathrm{ml}^{-1}\right)$ for $10 \mathrm{~min}$. A Quantimet $600 \mathrm{~S}$ Image Analyser (Leica) connected to a Nikon Optiphot 2 fluorescence microscope via a Kappa CF 8/1 FMC monochrome video camera (Kappa Messtechnik) was used to quantify the relative area stained by GFP compared with the total area of the fungus after staining with calcofluor white. The use of two different filter blocks, one with excitation filters between 330 and $380 \mathrm{~nm}$ and a barrier filter at $420 \mathrm{~nm}$ and the other one with excitation filters between 450 and $490 \mathrm{~nm}$ and a barrier filter at $520 \mathrm{~nm}$ on the fluorescence microscope made it possible to specifically view the fluorescence of either calcofluor white or GFP.

Flow-through cell experiments. The flow-through cell is adapted to follow the growth of individual hyphal elements. It consists of a small chamber between two microscope slides, allowing the fungus to grow in two dimensions, mounted on the fluorescence microscope described earlier coupled to the image analysis system. Such a set-up facilitates quantification of the morphological properties of single hyphal elements. A number of spores (which develop into hyphal elements) were fixed to a microscope slide using poly-D-lysine. A continuous flow of medium was pumped through the chamber to provide fresh nutrient as described by Spohr et al. (1998). During the induction experiments the feeding medium first contained $1 \mathrm{~g}$ 
xylose $\mathrm{l}^{-1}$ as repressor carbon source, then $0.5 \mathrm{~g}$ maltose $\mathrm{l}^{-1}$ to induce gene expression. The experiments were carried out at pH 3.5 and ambient temperature. The induction was followed by measuring the greyscale intensity of pixels in the hyphae under fluorescent light. It was assumed that the intensity of a pixel correlated with the amount of GFP present in the fungus at that point.

\section{RESULTS}

\section{GFP expression in A. niger: physiological characterization}

In the transformant strain the red-shifted GFP gene was expressed under the control of the glucoamylase promoter. Glucoamylase secretion has been found to be regulated at the level of transcription by catabolite repression (Nunberg et al., 1984; Bhella \& Altosaar, 1988; Fowler et al., 1990). Nunberg et al. (1984) and Fowler et al. (1990) showed that the transcription of the glucoamylase gene can be induced by starch or maltose and is repressed by xylose. Fig. 1 shows a batch experiment carried out with xylose as carbon source and at $\mathrm{pH} 3.5$. The maximum specific growth rate of the biomass $\left(\mu_{\max }\right)$ was estimated to be $0 \cdot 18 \mathrm{~h}^{-1}$. That is similar to the $\mu_{\max }$ obtained during a batch experiment using glucose as carbon source. Furthermore, the biomass yield coefficients $\left[Y_{\mathrm{Sx}}=0.60 \mathrm{C}\right.$-mol biomass (C-mol carbon source $)^{-1}$ ] were also identical for both carbon sources. As long as the xylose concentration was above $20 \mathrm{mg} \mathrm{l}^{-1}$ in the medium, GFP expression was repressed and only background fluorescence was measured. After $40 \mathrm{~h}$ cultivation, where xylose was exhausted, GFP was expressed to a final titre of $14 \mathrm{mg}$ red-shifted GFP (g total protein) ${ }^{-1}$.

In xylose-limited continuous cultures, where the xylose concentration is very low, there was no repression of red-shifted GFP expression. At a dilution rate of $0 \cdot 1 \mathrm{~h}^{-1}$, the specific productivity was $2.5 \mathrm{mg}$ red-shifted GFP ( $\mathrm{g}$ intracellular protein) ${ }^{-1} \mathrm{~h}^{-1}$. In order to examine the

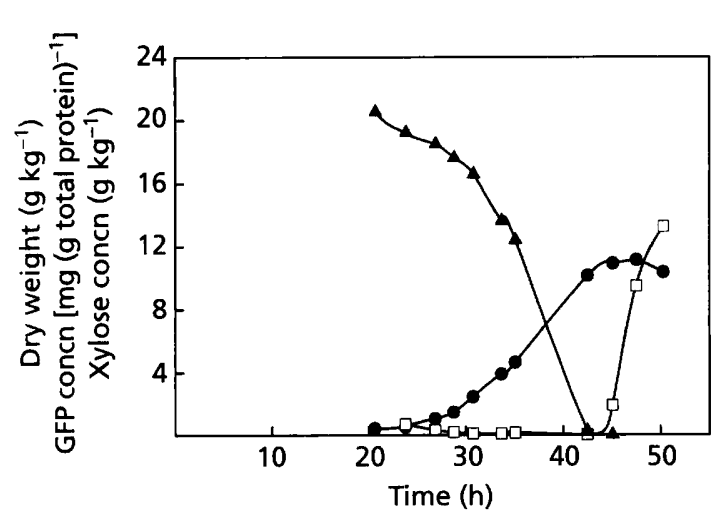

Fig. 1. Biomass, xylose and GFP concentrations as a function of time during batch culture in a defined medium containing xylose as carbon source. 0 , Biomass concentration; $\square$, redshifted GFP [mg (g total intracellular protein $)^{-1}$ ]; $\boldsymbol{\Delta}$, xylose concentration in the medium.

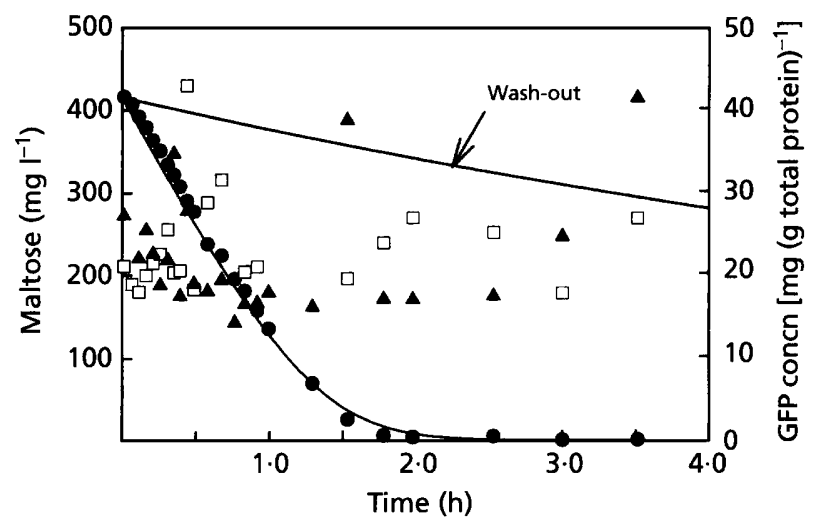

Fig. 2. Maltose pulse during a xylose-limited continuous culture at a dilution rate of $0.1 \mathrm{~h}^{-1}$. Maltose consumed during the pulse; $\square$, red-shifted GFP [mg (g total intracellular protein) ${ }^{-1}$ ] as determined by spectrofluorometry; $\boldsymbol{\Delta}$, red-shifted GFP [mg (g total intracellular protein) $\left.{ }^{-1}\right]$ as determined by electrophoresis. The wash-out curve represents a simulation of the maltose wash-out after the pulse due to the experimental setup.

dynamics of cytoplasmic production of GFP, during continuous cultivations operated at non-inducing conditions with xylose as the sole carbon source, a pulse of maltose, an inducing substrate, was added. Fig. 2 shows the maltose concentration after the pulse addition together with the wash-out profile of maltose, i.e. the profile of the maltose concentration if there was no consumption of this sugar.

The intracellular concentration of red-shifted GFP during the dynamic experiment was measured using SDS-PAGE by comparing with standards of red-shifted GFP. Under non-inducing conditions the steady state level was $25 \mathrm{mg}$ red-shifted GFP (g intracellular protein) ${ }^{-1}$, and during the maltose pulse the GFP concentration was approximately constant as shown in Fig. 2.

The samples were also analysed using a fluorescence spectrophotometer at an excitation wavelength of $470 \mathrm{~nm}$ and an emission wavelength of $510 \mathrm{~nm}$. Redshifted GFP could be detected throughout the experiment and the data were similar to those obtained using SDS-PAGE (Fig. 2).

\section{GFP expression in A. niger: morphological characterization}

Using image analysis the morphology of a filamentous micro-organism can be studied both at the population level or at the individual element level depending on the experimental set-up. A sample taken out of a bioreactor is usually considered as representative of a population, and from measurement of a certain number of elements (e.g. 50-100 elements) the mean properties of the population can be quantified. For this the Hyphal Growth Unit (HGU), as defined by Caldwell \& Trinci (1973), is a useful parameter. It is the ratio between the 


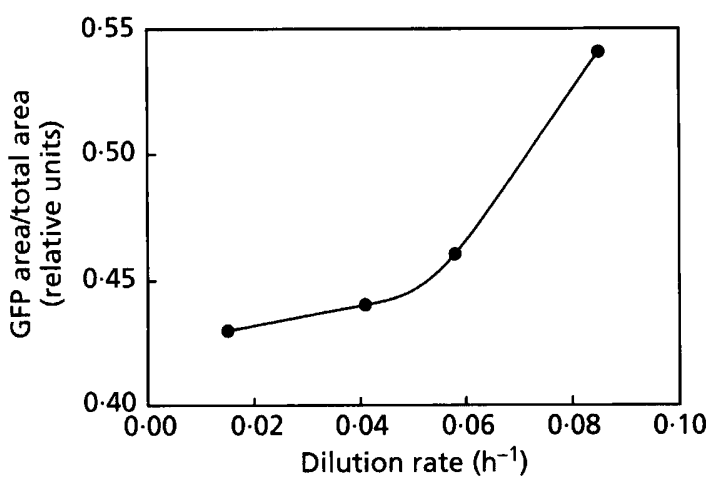

Fig. 3. Proportion of mycelium stained with red-shifted GFP as a function of the specific growth rate during glucose-limited continuous cultures.

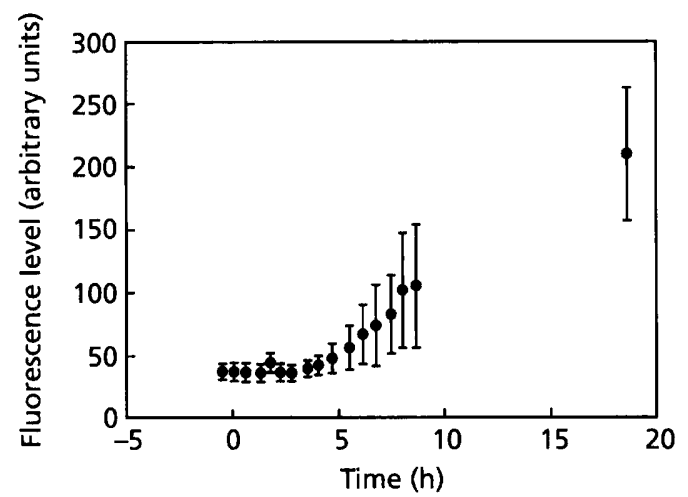

Fig. 4. Expression of GFP in hyphae during the induction experiment in the growth chamber. At time zero the carbon source was shifted from xylose to maltose.

total hyphal length and the number of tips, and it supplies information about the branching frequency of the fungus, i.e. for a densely branched hyphal element the HGU is low and vice versa. During the glucoselimited continuous cultures at different specific growth rates, samples were taken out of the bioreactor and the morphology of the hyphal elements was quantified using image analysis. From these measurements the HGU was estimated and remained fairly constant at different specific growth rates. Using fluorescence microscopy the area stained with red-shifted GFP was also measured and compared to the total area of the hyphae. The fraction of mycelium stained with red-shifted GFP was found to increase with increasing dilution rate as shown in Fig. 3.

By fixation of spores on a microscope slide mounted on an automatic stage one can study the morphology at the single element level (Spohr et al., 1998). Two parameters, the maximum specific growth rate, $\mu_{\max }$, and the characteristic tip extension rate, $k_{\text {tip }}$, were determined for many single elements and mean values were calculated from these data. Using morphological data $\mu_{\max }$ was estimated to be $0.26 \mathrm{~h}^{-1}$ for the transformed strain grown on glucose. The $k_{\text {tip }}$ was found to be $29 \mu \mathrm{m} \mathrm{h}^{-1}$. The same set-up can also be used to study the induction of red-shifted GFP expression inside the hyphae by switching from a medium containing xylose to one containing maltose. At the beginning of the experiment the spore population was estimated to contain $40 \%$ non-GFP-containing spores by numeration under a fluorescence microscope. Focusing on non-GFP-containing spores and developing hyphal elements, the dynamics of induction were examined. GFP appeared in the cytoplasm of germinating hyphae several hours after changing to a medium containing maltose. The intensity of fluorescence of the hyphal area expressing GFP was plotted as a function of time after the medium shift (Fig. 4). The intensity of the pixels measured increased when GFP was produced and the time delay between the medium shift and the detection of the chromophore was between 3 and $6 \mathrm{~h}$. Moreover the intensity of the fluorescence measured still increased $21 \mathrm{~h}$ after the shift to maltose as carbon source. During these experiments the fungus was exposed for several hours to UV light without bleaching (data not shown).

\section{DISCUSSION}

Recently a large number of reports on the utilization of GFP as a marker of gene expression and protein localization have been published (Takada et al., 1997; Inouye \& Tsuji, 1994; Terry et al., 1995; Suelmann et al., 1997; Cha et al., 1997). The fact that the protein has no requirement for other gene products from Aequorea victoria or for an exogenous substrate or energy source other than oxygen makes its detection very easy. In this study we reported the characterization of $A$. niger transformants expressing GFP in the cytoplasm under the control of the glucoamylase promoter. Only the transformations with an expression vector containing a synthetic GFP gene expressed a functional protein. Transformations with other vectors carrying the wildtype GFP expressed under various promoters did not result in GFP-expressing transformants (data not shown). The latest reports concerning GFP expression as a reporter gene also used a modified GFP gene (Suelmann et al., 1997; Bloemberg et al., 1997). The same observations were made in Schizosaccharomyces pombe, Candida albicans (Cormack et al., 1997) and in plants (Rouwendal et al., 1997; Haseloff et al., 1997). Spellig et al. (1996) first described problems with the expression of the wild-type GFP gene in Ustilago maydis. They used red-shifted GFP with codon usage optimized for higher plants described previously by Sheen $e t$ al . (1995).

\section{GFP expression in A. niger: physiological characterization}

Here a gene fusion strategy was applied to study the glucoamylase promoter. As reported earlier (Nunberg et al., 1984; Fowler et al., 1990), xylose acts as a repressor carbon source in batch cultivations (Fig. 1). However, 
when xylose was consumed red-shifted GFP was produced in the cytoplasm. When maleose was pulsed to a xylose-limited continuous culture the level of redshifted (iFP expressed in the cells seemed constant (Fig. 2). This seems to contradict previous reports on the induction effect of maltose and the repression of xylose on the glucoamylase promoter (Nunberg et al., 1984; Fowler et al., 1990). However, in the chemostat the residual concentration of xylose was too low to repress gene expression, a finding which is supported by the results of the batch experiment (Fig. 1) where there was a significant derepression of GFP production when the $x y$ lose concentration decreased below $20 \mathrm{mg} \mathrm{l}^{-1}$. The same phenomenon was reported for $x$-amylase with glicose as carbon source (Morkeherg et al., 1995). Here $x$-amylase production became glucose-repressed only at glucose concentrations above $10 \mathrm{mg} 1^{-1}$. Recently, Schrickx et al. (1993) also showed that a small amount of glucoamylase could he produced from $A$. niger during xylose-limited chemostat culture. Our results therefore contirm the fact that during xylose-limited continuous culture there is expression from the Pglat promoter, and this could he detected during the present study due to the high sensitivity of detection of (iFP' (between 0.01 and $1.5 \mathrm{mg} \mathrm{l}^{-1}$ ) with the fluorescence spectrophotometer compared with the traditional enzymic assay for glucoamylase $\left(12.5-625 \mathrm{mg} \mathrm{l}^{1}\right)$. The observation that the maltose pulse induction did not affect the steady state level of red-shifted GFP may he explained by the long lag time between induction and possible detection of the red-shifted CiFP, i.e. in the microchamber $5 \mathrm{~h}$ passed hefore there was an increase of hyphal fluorescence. The A. niger strain used was deleted for the glucoamylase gene, but it produced other amylases, and the deletion did therefore not impair growth on maltose, maltodextrin or starch. During the maltose pulse only the disaccharide was detected in the extracellular medium in the dynamic experiments. Moreover, maltose was clearly consumed since the maltose concentration decreased faster than the wash-out profile after the pulse (Fig. 2). This gives evidence for the presence of maltose transport in the strain.

\section{GFP expression in A. niger: morphological characterization}

During large-scale furmentation with filamentous fungi the usual explanation for low productivity is the hetcrogeneous state of the culture which results in variable levels of biological activity. A representative evaluation of the activity of a filamentous fungus is therefore essential in the simulation or prediction of a process (Agger et al., 1998). If one assumes that all the cells contaning cytoplasm are active then the strain of $A$. niger constructed during the present study can be used as an attractive alternative to the otherwise laborious staining procedures used to evaluate the activity of cells under protein production conditions (Agger et al., 1998).

The growth chamber results confirmed that GFP is visible under induced conditions only after several hours (between 4 and 5 hi. Therefore, as reported previously (Heim et al., 1994), the chromophore formation seems to be the rate-limiting step in visualization of GFP, and measurement of GFP can therefore not be uscd to monitor fast changes in promoter activity. The increase in fluorescence intensity up to $21 \mathrm{~h}$ after induction of GFP expression by maltose indicates that GFP is probably not degraded in the cells, due to the disruption of the gene, peptE, which encodes the major intracellular protease.

Despite these limitations in dynamic studies (iFP is a very sensitive expression marker which is easy to analyse. In promoter investigations of hydrolytic enzymes, like the glucoamylase, the product of the enzymic reaction often represses its own gene expression. Furthermore, in the case of glucoamylase the inducer - maltose - is rapidly degraded by the en7yme. It is therefore difficult to study induction and repression of enzymes like glucoamylase, but by applying a glucoamylase-deficient strain expressing GFP, the influence of malesse on product formation can be studied.

\section{ACKNOWLEDGEMENTS}

'Ihis project was partly financed by the E(I - Cell Factory Programme' Eurofung (project BIO4CT96-05.35). S.F. was partly financed by the FRASMUS programme from the Furopean Community. A.L.S.H. was financed by a Marie Curie stipend under the FU programme TMR projecr no. FRBFMBIC 1950.574 . The authors wish to thank Tina Johansen for her skilled technical help.

\section{REFERENCES}

Agger, T., Spohr, A. B., Carlsen, M. \& Nielsen, J. (1998). (irowth and product formation of Aspergillus oryade during submerged cultuvations: verification of a morphologically structured model using fluorescent probes. Biotechnol Bioeng 57, 321-329.

Banauch, D., Brummer, W., Ebeling, W., Metz, H., Rindfrey, H., Lang, H., Leybold, K., Rick, W. \& Staudinger, H. J. (1975). A glucose dehydrogenase for the determination of glucose concentrations in body fluids. Z. Klin (he'm Klin Biochem 13, 101-107.

Bhella, R. S. \& Altosaar, I. (1988). Role of CA.MP' in the mediation of glucose catabolite repression of glucoamylase synthesis in Aspergillus alumori. Curr (ienet 14, 247-252.

Bloemberg, G. V., O'Toole, G. A., Lugtenberg, B. J. J. \& Kolter, R. (1997). (ireen fluorescent protein as a marker for Psetudomonas spp. Appl linirom Microlnol 63, 4543-4551.

Bradford, M. M. (1976). A rapid and sensitive method for the quantitation of microgram quantities of protein utilizing the principle of proten-dye binding. And Biochem 72, 248-254.

Caldwell, I. Y. \& Trinci, A.P. J. (1973). The growth unit of the mould Geotrichum cundidum. Arsh Mikrobiol 88, 1-10.

Carlsen, M., Spohr, A. B., Nielsen, J. \& Villadsen, J. (1996). Morphology and physiology of an $x$-amylase producing strain of Aspergillus oryat during batch cultivations. Biotechnol Bioeng 49, 266-276.

Cha, H. J., Pham, M.-Q., Rao, G. \& Bentley, W. E. (1997). Expression of green thorescent protein in insect larvae and its application for heterologous protein production. Biotechnol Bioeng 56, 239-24. 
Chalfie, M. (1995). Green fluorescent protein. Photochem Photobiol 62, 651-656.

Chalfie, M., Tu, Y., Euskirchen, G., Ward, W. W. \& Prasher, D. C. (1994). Green fluorescent protein as marker for gene expression. Science 263, 802-805.

Christensen, L. H., Schulze, U., Nielsen, J. \& Villadsen, J. (1995). Acoustic off-gas analyser for bioreactors : precision, accuracy and dynamics of detection. Chem Eng Sci 50, 2601-2610.

Cocaign-Bousquet, M., Guyonvarch, A. \& Lindley, N. D. (1996). Growth rate-dependent modulation of carbon flux through central metabolism and the kinetic consequences for glucoselimited chemostat cultures of Corynebacterium glutamicum. Appl Environ Microbiol 62, 429-436.

Cody, C. W., Prasher, D. C., Westler, W. M., Prendergast, F. G. \& Ward, W. W. (1993). Chemical structure of the hexapeptide chromophore of the Aequorea green-fluorescent protein. Biochemistry 32, 1212-1218.

Cormack, B. P., Bertram, G., Egerton, M., Gow, N. A. R., Falkow, S. \& Brown, A. P. J. (1997). Yeast-enhanced green fluorescent protein (yEGFP): a reporter of gene expression in Candida albicans. Microbiology 143, 303-311.

Fernandez-Abalos, J. M., Fox, H., Pitt, C., Wells, B. \& Doonan, J. H. (1998). Plant-adapted green fluorescent protein is a versatile vital reporter for gene expression, protein localization and mitosis in the filamentous fungus, Aspergillus nidulans. Mol Microbiol 27, 121-130.

Fowler, T., Berka, R. M. \& Ward; M. (1990). Regulation of the glaA gene of Aspergillus niger. Curr Genet 18, 537-545.

Haseloff, J., Siemering, K. R., Prasher, D. C. \& Hodge, S. (1997). Removal of a cryptic intron and subcellular localization of green fluorescent protein are required to mark transgenic Arabidopsis plants brightly. Proc Natl Acad Sci USA 94, 2122-2127.

Heim, R., Prasher, D. C. \& Tsien, R. Y. (1994). Wavelength mutations and posttranslational autoxidation of green fluorescent protein. Proc Natl Acad Sci USA 91, 12501-12504.

Inouye, S. \& Tsuji, F. I. (1994). Aequorea green fluorescent protein. Expression of the gene and fluorescence characteristics of the recombinant protein. FEBS Lett 341, 277-280.

Misteli, T. \& Spector, D. L. (1997). Applications of the green fluorescent protein in cell biology and biotechnology. Nat Biotechnol 15, 961-963.

Mørkeberg, R., Carlsen, M. \& Nielsen, J. (1995). Induction and repression of $\alpha$-amylase production in batch and continuous cultures of Aspergillus oryzae. Microbiology 141, 2449-2454.

Nunberg, J. H., Meade, J. H., Cole, G. \& 7 other authors (1984). Molecular cloning and characterization of the glucoamylase gene of Aspergillus awamori. Mol Cell Biol 4, 2306-2315.

Plautz, J. D., Day, R. N., Dailey, G. M., Welsh, S. B., Hall, J. C., Halpain, S. \& Kay, S. A. (1996). Green fluorescent protein and its derivatives as versatile markers for gene expression in living Drosophila melanogaster, plant and mammalian cells. Gene 173, 83-87.
Prasher, D. C., Eckenrode, V. K., Ward, W. W., Prendergast, F. G. \& Cormier, M. J. (1992). Primary structure of the Aequorea victoria green-fluorescent protein. Gene 111, 229-233.

Rouwendal, G. J. A., Mendes, O., Wolbert, E. J. H. \& Douwe de Boer, A. (1997). Enhanced expression in tobacco of the gene encoding green fluorescent protein by modification of its codon usage. Plant Mol Biol 33, 989-999.

Schrickx, J. M., Krave, A. S., Verdoes, J. C., van den Hondel, C. A. M. J. J., Stouthamer, A. H. \& Van Verseveld, H. W. (1993). Growth and product formation in chemostat and recycling cultures by Aspergillus niger $\mathrm{N} 402$ and a glucoamylase overproducing transformant, provided with multiple copies of the glaA gene. J Gen Microbiol 139, 2801-2810.

Sheen, J., Hwang, S., Niwa, Y., Kobayashi, H. \& Galbraith, D. W. (1995). Green-fluorescent protein as a new vital marker in plant cells. Plant J 8, 777-784.

Siedenberg, D., Mestric, S., Ganzlin, M., Schmidt, M., Punt, P. J., van den Hondel, C. A. M. J. J. \& Rinas, U. (1998). GlaA promoter controlled production of a mutant green fluorescent protein (S65T) by recombinant Aspergillus niger during growth on defined medium in batch and fed-batch cultures. Biotechnol Prog (in press).

Spellig, T., Bottin, A. \& Kahman, R. (1996). Green fluorescent protein (GFP) as a new vital marker in the phytopathogenic fungus Ustilago maydis. Mol Gen Genet 252, 503-509.

Spohr, A., Dam-Mikkelsen, C., Carlsen, M., Villadsen, J. \& Nielsen, J. (1998). On-line study of fungal morphology during submerged growth using a small flow-through cell. Biotechnol Bioeng 58, 541-553.

Suelmann, R., Sievers, N. \& Fischer, R. (1997). Nuclear traffic in fungal hyphae: in vivo study of nuclear migration and positioning in Aspergillus nidulans. Mol Microbiol 25, 757-769.

Takada, T., lida, K., Awaji, T., Itoh, K., Takahashi, R., Shibui, A., Yoshida, K., Sugano, S. \& Tsujimoto, G. (1997). Selective production of transgenic mice using green fluorescent protein as a marker. Nat Biotechnol 15, 458-461.

Terry, B. R., Matthews, E. K. \& Haseloff, J. (1995). Molecular characterisation of recombinant green fluorescent protein by fluorescence correlation microscopy. Biochem Biophys Res Commun 217, 21-27.

Wang, S. \& Hazelrigg, T. (1994). Implications for bcd mRNA localization from spatial distribution of exu protein in Drosophila oogenesis. Nature 369, 400-403.

Webb, C. D., Decatur, A., Teleman, A. \& Losick, R. (1995). Use of green fluorescent protein for visualization of cell-specific gene expression and subcellular protein localization during sporulation in Bacillus subtilis. J Bacteriol 177, 5906-5911.

Received 27 July 1998; revised 23 October 1998; accepted 5 November 1998. 